Hanna Jadacka •

Uniwersytet Warszawski, Warszawa

h.jadacka@uw.edu.pl

\title{
CZY OPIS SYNCHRONICZNY SYSTEMU SŁOWOTWÓRCZEGO POLSZCZYZNY JEST KOMPLETNY?
}

Słowa klucze: alternacja morfonologiczna, derywacja alternacyjna, derywacja paradygmatyczna, derywacja prefiksalna, derywacja prefiksalna wymienna, derywacja ujemna, słowotwórstwo synchroniczne, techniki słowotwórcze

Keywords: morphophonological alternation, derivation by alternation, conversion, prefixation, derivation by exchange of prefixes, clipping, synchronic word formation, word-formation techniques

Jak przypomina Mirosław Skarżyński (1999a: 5), za początek słowotwórstwa opisowego zwykliśmy uważać rok 1959. Ukazał się wtedy artykuł Andrzeja Bogusławskiego O zasadach analizy morfologicznej (1959) i wywołał ożywioną dyskusję. Po upływie 60 lat można dokładnie odtworzyć stadia rozwoju tej (sub)dyscypliny językoznawczej oraz przedstawić kierunki i rezultaty podjętych wysiłków badawczych.

Czterdziestolecie 1959-1999 zostało wnikliwie scharakteryzowane w monografii Powstanie i rozwój polskiego słowotwórstwa opisowego (Skarżyński 1999a). Nie mamy jednak zwartego opisu stanu słowotwórstwa synchronicznego w ostatnim dwudziestoleciu, które obfitowało w ważne, niekiedy nawet przełomowe ustalenia. W artykule niniejszym spróbuję połączyć oba etapy ewolucji interesującej nas tu dziedziny, by w efekcie uzyskać odpowiedź na tytułowe pytanie, a także uwypuklić rolę, jaką w rozwoju tej dyscypliny odegrał jeden z jej najwybitniejszych reprezentantów Profesor Mirosław Skarżyński.

Dokonał on nie tylko krytycznej analizy badań prowadzonych w latach 19591999, lecz także udoskonalił opis systemu słowotwórczego w latach 1999-2019, nieobjętych syntezą z 1999 r., za to najważniejszych w biografii naukowej Autora. 
Pierwsze prace $\mathrm{z}$ dziedziny słowotwórstwa synchronicznego skupiały się na analizach opozycji binarnych, których jeden człon był uznawany za motywujący (badać), drugi - za motywowany (bad-acz). Taki opis miał ukazać system derywacyjny jako zbiór typów słowotwórczych, czyli modeli tworzenia wyrazów, definiowanych jako połączenie tematów i formantów. Typy słowotwórcze układające się w zbiory derywatów o tym samym znaczeniu, czyli z formantami o podobnej funkcji semantyczno-słowotwórczej, to hierarchicznie wyższe jednostki opisu - kategorie słowotwórcze. Owo skoncentrowanie się na formancie przyświecało wielu ówczesnym badaczom, także autorkom trzech tomów Słowotwórstwa współczesnego języka polskiego (Grzegorczykowa, Puzynina 1979; Waszakowa 1993, 1994).

Tę jednostronność podejścia badawczego otwarcie krytykowała Maria Honowska już w 1967 r.:

Prawidłowa analiza słowotwórstwa słowiańskiego [...] musi [...] uwzględnić słowotwórczy charakter podstawy derywacyjnej, nie może poprzestać na określeniu jej charakteru jako części mowy, podstawy bowiem pochodne zdolne są całkowicie zmienić obraz funkcyjny derywatu (Honowska 1967: 69).

Komentujący ten stan rzeczy Mirosław Skarżyński trafnie zauważył, że:

[...] system słowotwórczy, mimo ujmowania go w typy i kategorie, robi wrażenie luźnego dość zbioru par wyrazowych, a przynajmniej [...] nie zawiera w sposób jawny informacji o tym, że relacje motywacyjne nie wyczerpują się w zbiorze leksyki na poziomie dwójek wyrazowych. Ponadto temat słowotwórczy jest traktowany w jakimś sensie drugoplanowo, co o tyle robi dziwne wrażenie, że zawsze przecież widziano w nim główną część wyrazu motywowanego (Skarżyński 1999a: 154).

Ograniczenia, wynikające z takiego ujęcia, ujawniły się z całą ostrością przy analizie konkretnych, szczegółowych relacji motywacyjnych między członami opozycji binarnych. Niektóre z tych relacji okazały się tak zawiłe, że dostępnymi wówczas metodami nie można było ich precyzyjnie zaszeregować. Ślad owych trudności odzwierciedlają terminy: motywacja wzajemna i wielomotywacyjność ${ }^{1}$.

W tym nurcie sytuowały się też prace na temat różnego typu relacji motywacyjnych w parach słowotwórczych, wykorzystujące schemat klasyfikacyjny Miloša Dokulila (1962). Eksponowano w nich formanty powodujące istotną zmianę semantyczną $\mathrm{w}$ derywacie $\mathrm{w}$ stosunku do leksemu podstawowego i fakultatywną zmianę składniową (w derywatach mutacyjnych), zmianę niewielką, bez zmiany syntaktycznej (w derywatach modyfikacyjnych), oraz zmianę tylko składniową (w formacjach transpozycyjnych). Już na starcie ujawniły się kłopoty z respektowaniem zasady rozłączności podziału derywatów od poszczególnych części mowy na wymienione wyżej trzy podzbiory. Ilustracją tych kłopotów jest np. następująca deklaracja współautorek Morfologii:

1 Terminy używane przez Renatę Grzegorczykową i Jadwigę Puzyninę w Morfologii. 
Ze względu na trudność oddzielenia w derywatach czasownikowych mutacji od modyfikacji w szczegółowym opisie czasownika [...] połączono je w jedną grupę derywatów semantycznych (GWJP 1998 II: 379).

Ważnym etapem (składnikiem) badań prowadzonych w latach 1959-1999 była debata nad słowotwórczą rolą fleksji, zakończona zdefiniowaniem techniki derywacyjnej, którą ostatecznie nazwano derywacja paradygmatyczną, oraz precyzyjnym wyznaczeniem jej zakresu znaczeniowego. Cennym efektem naukowej refleksji lat 1964-1992 (czyli od publikacji artykułu Romana Laskowskiego i Henryka Wróbla (1964) do ukazania się pracy Krystyny Waszakowej (1993)) było opanowanie chaosu terminologiczno-pojęciowego, tak typowego dla wcześniejszych prac słowotwórczych. Hanna Jadacka przypomina, że:

Derywację prostą niemającą jednoznacznych cech prefiksacji ani sufiksacji nazywano: derywacja fleksyjna, paradygmatyczna, ujemną, wsteczną, zerowa oraz konwer$s j a^{2}$. Pod tymi szyldami kryły się zjawiska niejednorodne, bo obejmujące rezultaty takich procesów derywacyjnych, jak: śpiewać $\rightarrow$ śpiew, pracować $\rightarrow$ praca, dyrektor $\rightarrow$ dyro, specjalista $\rightarrow$ spec, matematyka $\rightarrow$ matma, znajomy $\rightarrow$ znajoma, lis $\rightarrow$ lisi, wokalny $\rightarrow$ wokal (Jadacka 2017: 90).

Rozprawa Waszakowej, odwołująca się do bogatego materiału i podbudowana wnikliwą refleksją teoretyczną, wyznaczyła badanej technice słowotwórczej zakres znacznie większy, niż proponowali wcześniej inni autorzy (por. Laskowski, Wróbel 1964; Kurzowa 1974; Kreja 1974, 1975). Dzięki tej pracy w sposób jednoznaczny oddzielona została derywacja prefiksalna od sufiksalnej (por. Waszakowa 1991), natomiast na precyzyjne wyodrębnienie derywacji ujemnej przyszło nam jeszcze kilka lat poczekać (por. s. 72-73), podobnie jak na istotną zmianę hierarchiczną w podejściu do badanych komponentów systemu słowotwórczego.

Kilkanaście lat po podjęciu prac nad synchroniczną analizą relacji formalno-semantycznych w opozycjach binarnych pojawiły się próby zastosowania w słowotwórstwie metody gniazdowej, $\mathrm{z}$ powodzeniem stosowanej w językoznawstwie rosyjskim $^{3}$ (S.K. Szaumian, P.A. Sobolewa, A.N. Tichonow).

Metodą zainteresował się M. Skarżyński już w 1979 r., wkrótce adaptował ją dla polszczyzny i twórczo rozwinął w kilku obszernych pracach ${ }^{4}$.

2 Opis systemu derywacyjnego w podręczniku R. Grzegorczykowej zawierał następujące terminy: słowotwórstwo afiksalne (sufiksalne, prefiksalne, prefiksalno-sufiksalne); słowotwórstwo paradygmatyczne (derywacja zerowa), z przykładami dźwig, obstawa, psi, bezludzie; słowotwórstwo syntaktyczne (konwersja): uczony, biegiem; derywacja wsteczna (ujemna): szpila $\leftarrow$ szpilka (Grzegorczykowa 1972: 38-39).

3 Jeszcze przed lingwistami rosyjskimi potrzebę badania całych sieci relacji między derywatami od wspólnej podstawy postulował Józef Wierzchowski (1959).

4 Por. zwłaszcza: Skarżyński 1981a, b, 1982, 1985, 1986a, b, 1989. 
Jego zdaniem, podstawowym wyróżnikiem nowego sposobu opisu była zmiana perspektywy badawczej:

[...] formacje widziane dotąd z pozycji formantu zaczęły być obserwowane z pozycji tematu słowotwórczego, prostego w centrum obiektu, który nazwano słowotwórczym gniazdem, i rozbudowywanego stopniowo, w miarę oddalania się od centrum w kolejnych taktach derywacyjnych (stopniach pochodności), na których lokują się derywaty. Konstruowanie takiego gniazda opiera się na założeniach synchronicznego słowotwórstwa, $\mathrm{w}$ innym bowiem wypadku gniazdo nie byłoby modelem mikrostruktury współczesnych relacji motywacyjnych, ale pokazywałoby efekty procesów diachronicznych (Skarżyński 1999a: 155).

Niebawem nowa metoda zainteresowała słowotwórców warszawskich. W środowisku tym powstał plan opracowania słownika gniazdowego współczesnej polszczyzny. Prace te zainicjowała Jadwiga Puzynina, a w składzie kierowanego przez nią zespołu były m.in. Alina Grochowska, Renata Grzegorczykowa, Hanna Jadacka, Alicja Nagórko i Krystyna Waszakowa. Zapowiedzią nowego leksykonu były dwie publikacje: artykuł H. Jadackiej i A. Nagórko w „Poradniku Językowym” (Jadacka, Nagórko 1985) oraz Zeszyt próbny słownika gniazd słowotwórczych współczesnego języka polskiego (Jadacka 1988). Powstała już wtedy monografia gniazdowa przymiotnika ${ }^{5}$, a kilka lat później - rzeczownika (zob. Jadacka 1995).

Przydatność opisu gniazdowego dla rozwoju omawianej dyscypliny trudno dziś przecenić. Mirosław Skarżyński tak ujął korzyści płynące ze stosowania tej metody:

1. Pozwala [...] w dużym stopniu poszerzyć wiedzę o systemie derywacyjnym języka poprzez możliwość opisu siatki relacji motywacyjnych między wyrazami w całości zbioru słownikowego.

2. Pozwala ustalić inwentarz modeli słowotwórczych ${ }^{6}$ języka wraz $\mathrm{z}$ informacją o stopniu ich wykorzystania i ogólnych regułach ograniczających aktywność słowotwórczą [...].

3. Dostarcza empirycznych podstaw dla działań normatywnych w zakresie oceny neologizmów (Skarżyński 1999b: 206-207).

Nacisk na jednoznaczność leksemów tworzących gniazdo pozwolił ograniczyć dowolność interpretacyjną wielu opozycji binarnych, uściślić opis derywatów oraz usunąć dotychczasowe (rzekome) bariery związane z ustalaniem kierunku motywacji. Przy tej okazji potwierdzono na bogatym materiale przydatność parafrazy słowotwórczej jako narzędzia pomagającego wyeliminować nieostrość rozstrzygnięć, tak niepożądanych w analizach naukowych?

5 To rozprawa doktorska Teresy Vogelgesang. Skrót tej pracy ukazał się w „Poradniku Językowym”, zob. Vogelgesang 1984.

6 Tzn. symbolicznych zapisów odtwarzających układ zmian części mowy w procesie derywacyjnym [uzup. - H.J.].

7 O innych jeszcze zastosowaniach metody gniazdowej zob. Jadacka 1987a, b. 
Mimo tego opis gniazdowy $\mathrm{z}$ trudem torował sobie miejsce w syntezach słowotwórczych oraz podręcznikach akademickich. Po ukazaniu się około sześćdziesięciu prac przedstawiających i wykorzystujących tę metodę M. Skarżyński pisał nie bez goryczy:

[...] w akademickiej Gramatyce współczesnego języka polskiego [1984, 1998 - H.J.] ten nurt badań nad słowotwórstwem nie został uwzględniony ani w pierwszym, ani w drugim wydaniu, mimo że w czasie, gdy przygotowywano wydanie drugie, stan wiedzy o gniazdach słowotwórczych skłaniałby do uwzględnienia tego nurtu interpretacyjnego (Skarżyński 1999a: 174).

Sam tylko autor tych słów opublikował już wtedy kilka artykułów na temat metody gniazdowej (zob. Skarżyński 1981a, 1982, 1986a, b, 1999b), a jej przydatność udokumentował w rozprawie doktorskiej (Skarżyński 1985) oraz w dwóch słownikach (zob. Skarżyński 1981b, 1989).

Powstałe w omawianym czterdziestoleciu studia, monografie i podręczniki akademickie ${ }^{8}$ przyniosły wstępny opis systemu słowotwórczego, jego jednostek operacyjnych, składników leksykalnych i morfologicznych oraz narzędzi badawczych. Techniki słowotwórcze uznane za sterujące działaniem poszczególnych części tego systemu to:

- sufiksacja,

- prefiksacja,

- derywacja wymienna,

- derywacja paradygmatyczna,

- derywacja alternacyjna (jakościowa i ilościowa),

- derywacja mieszana (prefiksalno-sufiksalna, prefiksalno-paradygmatyczna).

Analizom materiałowym towarzyszyło powstawanie, uzupełnianie i porządkowanie terminologii kształtującej się dziedziny wiedzy. Rezultaty tych działań (obejmujących nie tylko słowotwórstwo synchroniczne) rejestruje skrupulatnie Słownik przypomnień gramatycznych (Skarżyński 200o), pomyślany przede wszystkim jako pomoc dydaktyczna.

W prezentacji stanu systemu słowotwórczego na przełomie wieków pozostawiono sporo wolnej przestrzeni, otwartej na działania porządkujące, uzupełniające i korygujące. W następnych latach skwapliwie wykorzystano tę szansę. Badania przeprowadzone w dwudziestoleciu 1999-2019 doprowadziły do wyodrębnienia nowych technik słowotwórczych oraz przegrupowania zakresowego między technikami rozpoznanymi wcześniej. Ważną konsekwencją tych zmian była marginalizacja niektórych technik, a później podważenie ich statusu naukowego. Szybko okazało się, jak ogromną przydatność ma włączenie do tego opisu gniazd słowo-

8 Por. zwłaszcza: Kreja 1963, 1974; Laskowski, Wróbel 1964; Honowska 1967; Grzegorczykowa 1972; Kurzowa 1974; Grzegorczykowa, Puzynina 1979; Waszakowa 1993. 
twórczych, a zwłaszcza jakie szanse badawcze otwiera ich zbiorcze opracowanie leksykograficzne9.

Pierwszego, ogromnie ważnego dowodu dostarczyła monografia Iwony Kaproń-Charzyńskiej Derywacja ujemna w języku polskim. Rzeczowniki i przymiotniki (Kaproń-Charzyńska 2005), uzupełniona artykułem Czasowniki $z$ formantami ujemnymi (Kaproń-Charzyńska 2008). Rozprawa ta z powodzeniem kontynuuje opracowania poświęcone konkretnym technikom słowotwórczym ${ }^{10}$. Na podstawie wszechstronnej analizy 4800 rzeczowników i 1400 przymiotników autorka następująco definiuje elementy składowe badanej techniki:

Derywat ujemny to taki wyraz, który różni się od wyrazu motywującego tym, że brakuje mu pewnej niefleksyjnej części wyrazu motywującego. Brak w derywacie niefleksyjnej części wyrazu motywującego jest w derywacji ujemnej dystynkcją podstawową (Kaproń-Charzyńska 2005: 27).

Dodatkowe światło na zagadnienie derywacji ujemnej rzuca rozprawa Iwony Burkackiej Kombinatoryka sufiksalna w polskiej derywacji odrzeczownikowej (Burkacka 2012), potwierdzająca słowotwórczy charakter ucięć (tatar-ski /befsztyk/ $\rightarrow$ tatar $<>$, /kuracjal odwyk-owa $\rightarrow$ odwyk-<>, hero-ina $\rightarrow$ hera $<>$ ).

Syntetyczne opracowanie derywacji ujemnej nie było jedynym novum w sposobie widzenia technik słowotwórczych w ostatnich latach. Zespół opracowujący gniazda słowotwórcze od bazy czasownikowej doszedł do wniosku, że interpretowanie części czasowników dewerbalnych jako efektu tradycyjnie rozumianej prefiksacji jest niepoprawne semantycznie. Element znaczeniowy wnoszony przez prefiks $\mathrm{w}$ derywacie wymaga bowiem uwzględnienia semantyki przedrostka w czasowniku podstawowym, nieobecnym już w strukturze formalnej nowego leksemu. Mieliśmy zatem do czynienia $\mathrm{z}$ wymianą prefiksów, nie zaś z ich automatycznym dodaniem. Ilustrują to np. pary za-kręcić - od-kręcić, na-pisać - prze-pisać (odkręcić można rzecz uprzednio zakręcona, przepisać - coś najpierw napisanego, ale wyrazy motywowane nie mają postaci ${ }^{\star}$ od-zakręcić, ${ }^{\star}$ prze-napisać, jak typowe pary prefiksalne po-dopisywać - dopisywać, po-wynosić - wynosić).

Jako redaktor naukowy III tomu SGS M. Skarżyński podjął decyzję o zapisie ok. 300 czasowników jako derywatów prefiksalnych wymiennych (por. też Skarżyński 2003). Wkrótce podjęto szczegółową analizę zjawiska na dużej próbie materiałowej.

Wstępne wyniki tych działań przedstawiła Joanna Stankiewicz (2006), a Michał Wiśnicki (2010) poświęcił nowej technice derywacyjnej rozprawę doktorską. Kilka lat później Wanda Fijałkowska w pracy La dérivation par échange de préfixes au sein du système dérivationnel polonais et français (2019), opisała derywację prefiksalną wymienną z perspektywy kontrastywnej - polsko-francuskiej.

9 Na początku XXI w. ukazały się wszystkie cztery tomy Słownika gniazd słowotwórczych, zob. SGS. 10 Tzn. prace: Grzegorczykowa, Puzynina 1979; Waszakowa 1993, 1994. 
Niemal równolegle z tymi badaniami doszło do pewnych zmian $\mathrm{w}$ patrzeniu na derywację wymienna w znaczeniu, jakie nadał temu pojęciu Bogusław Kreja (1963: 133-140). Badacz ten odnosił derywacje wymienna tylko do poziomu sufiksalnego, na którym wyodrębniał kilka jej podrodzajów. Późniejsze analizy wykazały jednak, że prawie wszystkie przykłady opisane przez B. Kreję należałoby umieścić albo poza słowotwórstwem synchronicznym, albo w obrębie derywacji sufiksalnej ${ }^{11}$.

Funkcjonujące od lat 70. ubiegłego wieku terminy i pojęcia derywacja alternacyjna jakościowa oraz derywacja alternacyjna ilościowa ${ }^{12}$ zaczęły podlegać istotnemu przewartościowaniu. W miarę jak wzrastała ich ranga jako narzędzia opisu, zanikał ich związek z pierwotnym znaczeniem, jak również z morfologicznymi ograniczeniami ich użycia.

Alicja Nagórko wykazała, że formacje typu rąsia, ucho, Zosia, uchodzące za struktury alternacyjne jakościowe, są w istocie derywatami sufiksalnymi (Nagórko 1998: 184). Trafność tej hipotezy potwierdziła na bogatym materiale Krystyna Kallas (2010).

Analiza tzw. alternacji ilościowych, przeprowadzona przez I. Kaproń-Charzyńską (2005), udowodniła, że formacje takie, jak dyro, spec, amfa, matma to produkty derywacji ujemnej. Podobny pogląd na tę sprawę wyrażała H. Jadacka (2001: 31, 32, 2012: 137).

Zatem dzisiejszy system słowotwórczy to zbiór klas formacji wygenerowanych przez nadal aktywne techniki derywacyjne, czyli stymulatory jego rozwoju, a mianowicie:

- sufiksacje, wzbogaconą o formacje opisywane dotąd jako (sufiksalne) wymienne oraz o derywaty uważane wcześniej za alternacyjne jakościowe;

- prefiksację (dodatnia), uszczuploną o formacje prefiksalne wymienne;

- derywacje wymienna (prefiksalna i sufiksalna);

- derywacje paradygmatyczna (pomniejszoną o formacje uznane za produkty derywacji ujemnej);

- derywacje ujemna, na którą złożyła się duża część formacji uznawanych wcześniej za paradygmatyczne oraz alternacyjne ilościowe;

- derywację mieszana, obejmującą derywaty z więcej niż jednym formantem, tzn. prefiksalno-sufiksalne i prefiksalno-paradygmatyczne.

W ostatnim podzbiorze nie zaszły widoczne zmiany, gdyż derywaty prefiksalno-paradygmatyczne ujawniły się automatycznie w ślad za nakreśleniem i wyostrzeniem granic zakresowych derywacji paradygmatycznej.

Pora spytać: czy ustalenia dwudziestolecia 1999-2019 weszły do powszechnego obiegu naukowego, tzn. do kompendiów, syntez i podręczników akademickich?

11 Szczegółowo o tym w: Jadacka 2009: 277-284, 2017: 94-95.

12 W znaczeniu, jakie nadali jej m.in. R. Grzegorczykowa (1972: 37) i R. Laskowski (1978: 16-17), a powtórzył M. Skarżyński (200o: 18). 
Nie wszystkie nowsze ujęcia znalazły wystarczające odzwierciedlenie w literaturze przedmiotu; nie jest ona zresztą nadmiernie bogata. Najlepiej dokumentują je podręczniki A. Nagórko. W trzecim wydaniu Zarysu gramatyki polskiej (Nagórko 1998) integralną częścią działu słowotwórczego stał się opis gniazdowy. Gniazdo i jego części, tzn. łańcuchy i paradygmaty słowotwórcze, przedstawiono jako zhierarchizowane jednostki systemowe. Derywacja wymienna, obejmująca także prefiksy, została uwzględniona w Podręcznej gramatyce języka polskiego (Nagórko 2010), ale w zakresie ograniczonym tylko do tzw. podstaw zwiazanych ${ }^{13}$. Ujęcie zjawiska derywacji ujemnej jeszcze nie uwzględnia propozycji I. Kaproń-Charzyńskiej (2005, 2008).

W Systemie słowotwórczym... H. Jadackiej (2001) badane neologizmy nie są analizowane metodą gniazdową, gdyż, zdaniem autorki, taki zabieg miałby niewielką wartość naukową. Są natomiast w pracy wstępne sygnały o konieczności rewizji granic zakresowych derywacji ujemnej (ibid.: 28-30, 55, 63, 114). Derywacja alternacyjna została omówiona zgodnie $\mathrm{z}$ ówczesnym stanem badań. $\mathrm{Z}$ powodów chronologicznych brak w rozprawie informacji o derywacji prefiksalnej wymiennej. Technika ta jest wymieniona dopiero w podręczniku Kultura języka polskiego. Fleksja, słowotwórstwo, składnia (Jadacka 2005: 106, 119).

Odpowiedź na pytanie tytułowe powinna zatem brzmieć: tak, opis synchroniczny systemu słowotwórczego polszczyzny jest w zasadzie kompletny. Brak dokładnego rejestru formantów nieciągłych oraz derywatów z takimi wykładnikami to kwestia bardziej techniczno-statystyczna niż naukowa. Jest to jednak opis rozproszony, wymaga zatem scalenia, choćby ze względów dydaktycznych. Synteza stanu wiedzy na temat współczesnego słowotwórstwa czeka więc na opracowanie. Okrutny los sprawił, że nie sporządzi jej badacz najbardziej do tego powołany - Profesor Mirosław Skarżyński.

\section{Literatura}

Burkacka I., 2012, Kombinatoryka sufiksalna $w$ polskiej derywacji odrzeczownikowej, Warszawa.

Dokulil M., 1962, Tvořeni slov v češtině, cz. 1: Teorie odvozováni slov, Praha.

FijaŁkowska W., 2019, La dérivation par échange de préfixes au sein du système dérivationnel polonais et français, Warszawa.

GrzegorCZy Kowa R., 1972, Zarys słowotwórstwa polskiego, cz. I: Słowotwórstwo opisowe, Warszawa.

Grzegorczy kowa R., Puzynina J., 1979, Słowotwórstwo współczesnego języka polskiego. Rzeczowniki sufiksalne rodzime, Warszawa.

13 Uwzględnienie tej techniki w opisach podręcznikowych byłoby łatwiejsze, gdyby rozprawa M. Wiśnickiego ukazała się drukiem. 
Grzegorczy kowa R., Puzynina J., 1984, Problemy ogólne słowotwórstwa, [w:] R. Grzegorczykowa, R. Laskowski., H. Wróbel (red.), Gramatyka współczesnego języka polskiego. Morfologia, Warszawa, s. 307-332.

GWJP I-II: R. Grzegorczykowa, R. Laskowski, H. Wróbel (red.), Gramatyka współczesnego języka polskiego. Morfologia, t. I-II, wyd. 2 zm., Warszawa 1998.

HonowsKa M., 1967, Zarys klasyfikacji polskich derywatów, Wrocław.

JADACKA H., 1987a, O przydatności opisu gniazdowego w badaniach nad polisemia i homonimią, „Poradnik Językowy” nr 1, s. 11-40.

JADACKA H., 1987b, Zagadnienie motywacji słowotwórczej w opisie gniazdowym, „Poradnik Językowy” nr 8, s. 576-585.

JADACKA H., 1988, Zeszyt próbny „Słownika gniazd słowotwórczych wspótczesnego języka polskiego", red. J. Puzynina, Warszawa.

JADACKA H., 1995, Rzeczownik polski jako baza derywacyjna. Opis gniazdowy, Warszawa.

JADACKA H., 2001, System słowotwórczy polszczyzny (1945-20oo), Warszawa.

JADACKA H., 2005, Kultura języka polskiego. Fleksja, słowotwórstwo, składnia, Warszawa.

JADACKA H., 2009, Nieporozumienia wokół nazw żeńskich, [w:] M. Skarżyński, M. Szpiczakowska (red.), W kręgu języka. Materiały konferencji „Słowotwórstwo - słownictwo polszczyzna kresowa" poświęconej pamięci Profesor Zofii Kurzowej. Kraków 16-17 maja 2008 r., „Biblioteka LingVariów”, t. 2, Kraków, s. 277-284.

JADACKA H., 2012, Status słowotwórczy tzw. alternacji ilościowych, [w:] H. Burkhardt, R. Hammel, M. Łaziński (red.), Sprache im Kulturkontext. Festschrift für Alicja Nagórko, Frankfurt am Main, s. 135-143.

JADACKA H., 2017, Ewolucja zakresu pojęciowego niesufiksalnych technik słowotwórczych, „LingVaria” nr 1 (23), s. 89-98, https://doi.org/10.12797/LV.12.2017.23.06.

JADACKA H., NAGóRKo A., 1985, O „Słowniku gniazd słowotwórczych współczesnej polszczy$z n y ”$, „Poradnik Językowy” nr 9/10, s. 555-580.

Kallas K., 2010, Słowotwórstwo polskich hipokorystyków imiennych, [w:] I. Burkacka, R. Pawelec, D. Zdunkiewicz-Jedynak (red.), Słowa - kładki, na których spotykają się ludzie różnych światów, Warszawa, s. 159-176.

Kaproń-Charzyńska I., 2005, Derywacja ujemna we współczesnym języku polskim. Rzeczowniki i przymiotniki, Toruń.

Kaproń-Charzyńska I., 2008, Czasowniki z formantami ujemnymi, „LingVaria” 1 (5), S. $49-60$.

Kreja B., 1963, Pojęcie derywacji wymiennej, „Z polskich studiów slawistycznych”, seria 2: "Językoznawstwo", Warszawa, s. 133-140.

KREJA B., 1974, Słowotwórcza rola fleksji we współczesnym języku polskim, „Studia Śląskie. Seria Nowa” t. 26, s. 193-205.

KREJA B., 1975, Kategorie fleksyjne w funkcji formantu słowotwórczego we współczesnym języku polskim, „Zeszyty Naukowe Uniwersytetu Gdańskiego. Prace Językoznawcze” nr 3, s. $49-55$.

Kurzowa Z., 1974, Derywacja fleksyjna w języku polskim oraz próba wyjaśnienia jej genezy, „Zeszyty Naukowe Uniwersytetu Jagiellońskiego. Prace Językoznawcze” nr 42, Kraków, s. 94-103.

Laskowski R., 1978, Alternacje morfonologiczne, [w:] S. Urbańczyk (red.), Encyklopedia wiedzy o języku polskim, Wrocław - Warszawa - Kraków - Gdańsk, s. 16-17. 
LASKOWSKi R., WRóBEL H., 1964, Użycie paradygmatu w funkcji formantu słowotwórczego we współczesnej polszczyźnie, „Język Polski” XLIV, s. 214-220.

NaGórko A., 1998, Zarys gramatyki polskiej (ze słowotwórstwem), wyd. 3 rozsz., Warszawa.

NAGór Ko A., 2010, Podręczna gramatyka języka polskiego, Warszawa.

SGS: Słownik gniazd słowotwórczych współczesnego języka ogólnopolskiego, t. I: Gniazda odprzymiotnikowe, T. Vogelgesang, Kraków 2001, t. II: Gniazda odrzeczownikowe, H. Jadacka (red.) oraz M. Bondkowska, I. Burkacka, E. Grabska-Moyle, T. Karpowicz, Kraków 2001, t. III: Gniazda odczasownikowe, M. Skarżyński (red.) oraz M. Berend, M. Bondkowska, I. Burkacka, H. Jadacka, M. Olejniczak, T. Vogelgesang, cz. 1-2, Kraków 2004, t. IV: Gniazda motywowane przez liczebniki, przysłówki, zaimki, przyimki, modulanty, onomatopeje, wykrzykniki, M. Skarżyński, Kraków 2004.

SKARŻYŃski M., 1981a, O nowym typie słowników jednojęzycznych, „Przegląd Humanistyczny" 7-9, s. 221-226.

SKARŻYŃsKi M., 1981b, Tworzenie wyrazów w języku polskim (Zeszyt próbny słownika słowotwórczego języka polskiego, litery A-D), Kielce.

SKARŻYŃsKi M., 1982, Słownik gniazdowy jako metoda opisu słowotwórczego, [w:] J. Tokarski (red.), Język - teoria - dydaktyka. Materiały V Konferencji Młodych Językoznawców-Dydaktyków, Nowa Wieś Szlachecka, 16-17 maja 1980 r., Kielce, s. 115-123.

SKarżyński M., 1985, Próba zastosowania metody analizy gniazdowej do badań systemu słowotwórczego współczesnej polszczyzny, rozprawa doktorska, mszps.

SkARżyński M., 1986a, Próba określenia możliwości słowotwórczych rzeczownika, [w:] M. Preyzner (red.), Język - teoria - dydaktyka. Materiały VII Konferencji Młodych Językoznawców-Dydaktyków, Trzemeśnia, 2-4 VI 1982 r., Kielce, s. 41-65.

SKARŻYŃSKi M., 1986b, Słowotwórcze gniazda odliczebnikowe, „Polonica” XII, s. 157-172.

SKARŻYŃski M., 1989, Mały słownik słowotwórczy języka polskiego dla cudzoziemców, Kraków.

SKARŻYŃsKi M., 1999a, Powstanie i rozwój polskiego słowotwórstwa opisowego, Kraków.

SKARŻYŃsKi M., 1999b, Stan obecny i perspektywy słowotwórstwa synchronicznego, [w:] M. Brzezina, H. Kurek (red.), Collectanea linguistica in honorem Casimiri Polański, Kraków, s. 199-208.

SKARŻYŃsKi M., 2000, Słownik przypomnień gramatycznych, Kraków.

SKARŻYŃsKi M., 2003, Słowotwórcze gniazda odczasownikowe (charakterystyka wstępna), [w:] idem (red.), Słowotwórstwo gniazdowe. Historia, metoda, zastosowania, Kraków, S. $137-155$.

STANKIEWICZ J., 2006, Wymiana prefiksów w derywacji odczasownikowej (na materiale gniazdowym), „Poradnik Językowy” nr 10, s. 119-126.

VOGELGESANG T., 1984, Budowa gniazd słowotwórczych przymiotników we współczesnym języku polskim, „Poradnik Językowy” nr 4, s. 230-240.

Waszakowa K., 1991, Derywacja sufiksalna, paradygmatyczna czy ujemna „Polonica” XVI, S. 101-110.

Waszakowa K., 1993, Słowotwórstwo wspótczesnego języka polskiego. Rzeczowniki z formantami paradygmatycznymi, Warszawa.

Wasza Kowa K., 1994, Słowotwórstwo współczesnego języka polskiego. Rzeczowniki sufiksalne obce, Warszawa.

Wierzchowski J., 1959, Uwagi słowotwórczo-leksykologiczne, „Biuletyn Polskiego Towarzystwa Językoznawczego" XVIII, s. 223-229. 
Wiśnicki M., 2010, Derywacja prefiksalna wymienna w czasownikach polskich (na materiale gniazdowym), rozprawa doktorska, mszps.

\section{Is the Synchronic Description of the Word-Formation System in Polish Complete? Summary}

The paper describes sixty years of the development of studies on synchronic word formation in Poland. The period is divided into two stages: 1959-1999, and 1999-2019. The first part recalls the comprehensive, profound characterization of the forty-year period from 1959 to 1999, given by Mirosław Skarżyński in Powstanie i rozwój polskiego słowotwórstwa opisowego. The second part is devoted to the twenty years from 1999 to 2019, and presents the most important changes that occurred in this period in the description of our (sub)discipline of linguistics. It highlights M. Skarżyński's influence on the direction and essence of those changes, as the personality who inspired and penned groundbreaking works in the field, especially as the editor and collaborator on the third volume of SGS. Not all of the findings presented in this dictionary are sufficiently known in the scientific millieu, primarily due to the dispersion of works that continue previous research. Only after a synthesis of the newest accomplishments is prepared, will it be possible to give a positive answer to the question in the title. 